\title{
Exploring Alternatives for Sustainable Development in the Tamiahua Wetlands
}

\author{
Luis Felipe Luna-Reyes*, Jorge A. Durán-Encalada**, \\ Erick R. Bandala***
}

\begin{abstract}
This article presents a preliminary System Dynamics model developed to analyze the sustainability of a natural reserve in Mexico: the Tamiahua Wetlands. Wetlands are often referred to as nature's kidneys because they filter contaminants from water. In spite of their importance, wetlands are endangered areas around the world. In order to build the model we take into account the Fishbanks model developed by Meadows (2004) as a starting point. Then, the model considers variables related to changes in total and economically active populations, and contaminants in water. The preliminary model presented in this study implies that fishing activity in the Tamiahua Wetlands, together with contaminants from human activity, have the potential to damage the diversity of species in the ecosystem, endangering its sustainability. Continued work on the model is intended to explore appropriate ways of preserving Tamiahua, providing inhabitants with economic activities that promote the sustainability of the region.
\end{abstract}

Keywords: sustainable development, Wetlands, Mexico, Tamiahua.

\section{Introduction}

This article introduces a preliminary System Dynamics model to analyze sustainability of a natural reserve located in the Northern bound of the State of Veracruz in Mexico: the Tamiahua Wetlands. The model presented in this study is the result of initial conversations among researchers interested in regional development and the preservation of the Tamiahua protected area, and builds upon such System Dynamics models as Fishbanks (Meadows, 2004). One of the authors of this initial study has been involved in extensive field research in Tamiahua, collecting information about water quality. During his fieldwork, he has observed a growth in the fishing industry followed by

\footnotetext{
* Luis Felipe Luna-Reyes, Ph.D., Universidad de las Américas Puebla, Business School, luisf.luna@udlap.mx, Santa Catarina Mártir, Cholula, Mexico, 72810, Phone: +52 (222) 229-2060, Fax: +52 (222) 229-2062.

** Jorge A. Durán-Encalada, Ph.D., Universidad de las Américas Puebla, Business School, jorgea.duran@udlap.mx, Santa Catarina Mártir, Cholula, Mexico, 72810, Phone: +52 (222) 229-2060, Fax: +52 (222) 229-2062.

*** Eric R. Bandala. Ph.D., Universidad de las Américas Puebla, School of Engineering, erick.bandala@udlap.mx, Santa Catarina Mártir, Cholula, Mexico, 72810, Phone: +52 (222) 229-2031.
} 
a decline on the activity of fishing cooperatives. The reduction in fishing appears to be the result of a combination of such factors as increased fishing activity, contamination and deterioration of the diversity of species in the wetlands region.

The document is organized in five more parts. The second section consists of a literature review on the nature and characteristics of wetlands, and the use of System Dynamics as a tool to study sustainability of fishing. The third section describes the methods used in the study. The next two parts: Analysis and Results and Discussion, describe the model structure and some interesting behaviors of the model TAMIAHUA1, respectively. Finally, the last section offers some final remarks and suggestions for further work.

\section{Literature review}

Wetlands are often referred to as nature's kidneys because they readily filter contaminants from water, there are also famous for their intrinsic beauty and importance as habitat for rare and endangered species as well as their role in carrying out basic ecological functions such as primary productivity, decomposition, nutrient cycling and regulation of fluxes between land and water bodies. These ecosystems can also function to remove and store nutrients and toxic pollutants in runoff from surrounding areas.

Particularly, coastal wetlands play an important role in protecting coastal water quality. They are critical ecosystems that help to regulate and maintain the hydrology by storing and releasing floodwaters. Wetlands are hard to define mainly because they are transition zones. Their hydrology is usually the most important factor determining its character. These regions are considered one of nature's most efficient filters and usually are important nurseries for fish, crabs, shellfish, and an extensive variety of animals.

Despite their importance in the ecosystems, wetlands are endangered zones all around the world. Only in the USA, an annual loss of approximately 1.05 million hectares of wetlands is estimated (Josephson, 1992). Apart from agricultural conversion, wetlands are continuously jeopardized as result of overfishing, burgeoning development, sediment contamination and nutrient pollution, all this is the result of growing population and increasing unplanned development in coastal counties. Such situation in many cases promotes excessive exploitation of fisheries and an increasing number of threatened, endangered and extinct indigenous species.

System Dynamics has been used in exploring the environmental management and sustainability in applications that tackle problems of forestry in Indonesia, irrigated lands in Spain, renewable resource management in Norway, wildlife management in the USA and blue-green algae bloom in the 
coastal waters of Australia (Cavana and Ford, 2004). What these applications have revealed is that modeling dynamically these complex problems with many factors can enlighten the implementation of possible policies to alleviate the problem. System Dynamics has proven to be a useful tool when complex systems need to be re-oriented towards greater sustainability through policies that are quite different from those currently implemented and which should focus on the true driving factors of the system (Martínez Fernández and Esteve Selma, 2004). Our study subscribes to these assumptions and aims.

Particularly, System Dynamics has been used successfully to analyze and study fishing systems in a variety of ways (Morecroft, 2007; Otto and Struben, 2004; Ruth, 1995). Most of these previous efforts were focused on analyzing the problem known as the "Tragedy of the Commons" and policies to control overexploitation of fishing areas. The model presented in this article builds on previous work in System Dynamics and studies the impact of contaminants and of fishing activities on the diversity of species in Tamiahua Wetlands.

\section{Method}

It is clear, from the analysis of the research site, that to achieve a sustainable and holistic understanding of the complexity faced by the Tamiahua Wetlands and its stakeholders, we need to go beyond simply predicting the fishing activity. Economic and social variables interact dynamically with environmental and institutional variables.

To explore the effect of fishing on the interaction of other variables, a System Dynamics model was constructed. System Dynamics, originally known as Industrial Dynamics, is a creation of Jay Forrester in the 1960s at the Massachusetts Institute of Technology (Forrester, 1961). System Dynamics is essentially a methodology which uses the theory of information feedback and control in order to evaluate organizations and problems. The basic idea underpinning this approach is that any complex situation can be described in terms of stocks and flows; flows being main actions increasing or decreasing the stocks. System Dynamics assumes that things are interconnected in complex closed patterns of causality, and that the world is made up of flows, stocks and feedback loops. Other assumptions include that information flows are intrinsically different from physical flows, and that non-linearities and time-delays embedded in the system's structure are important to understand the system behavior (Sterman, 2000). The main focus of the methodology is to capture the structure of complex problems, representing it in terms of stocks, flows and feedback loops, which constitutes a dynamic hypothesis to explain problematic behaviors. The model structure and behavior are then 
compared with known relationships and behaviors in the system in several iterations.

System Dynamics has been used in a variety of contexts, as a problem evaluation on the premises that the structure of a system, that is the way the systems are connected, generates its behavior, aiming to predict the behavior of the system (Richardson and Pugh, 1989, Stave, 2003, Sterman, 2000). While statistical forecasting models rely on equations developed ex post, i.e. following observations, System Dynamics aims first to determine the systems structure consisting of positive and negative relationships between variables, feedback loops, systems archetypes, and delays (Sterman, 2000; Wolstenholme, 1982, 2003) followed by ex ante projection where future system states are replicated from the System Dynamics model (Winz and Brierley, 2007).

As already mentioned in this article, the modeling effort is based upon the knowledge and experience of two experts, one on regional development, and the other on water and environment. Although obtaining quantitative data to build the model has proven to be difficult, knowledge from field work on the region has been used to ensure a better understanding of behavior over time and structural hypotheses. The model is still in a preliminary stage, but initial model structure and some key parameters seem reasonable to expert judgment.

\section{Analysis}

\section{The Tamiahua Wetlands}

The Tamiahua Lagoon is located in the northern part of the state of Veracruz, Mexico. It is a coastal lagoon and covers an area of 217,500 acres, of 52.2 miles length, 9.6 miles width, and the depth of 2.2-3.3 yards. It has two water mouths, one in the north and another in the south, and is located in between two large rivers, Panuco in the north and Tuxpam in the south (see Figure 1).

There are some valuable natural resources in the area which comprise an important mangrove swamp towards the south of the lagoon and coral reef formations to the east, on the Gulf of Mexico coast. 

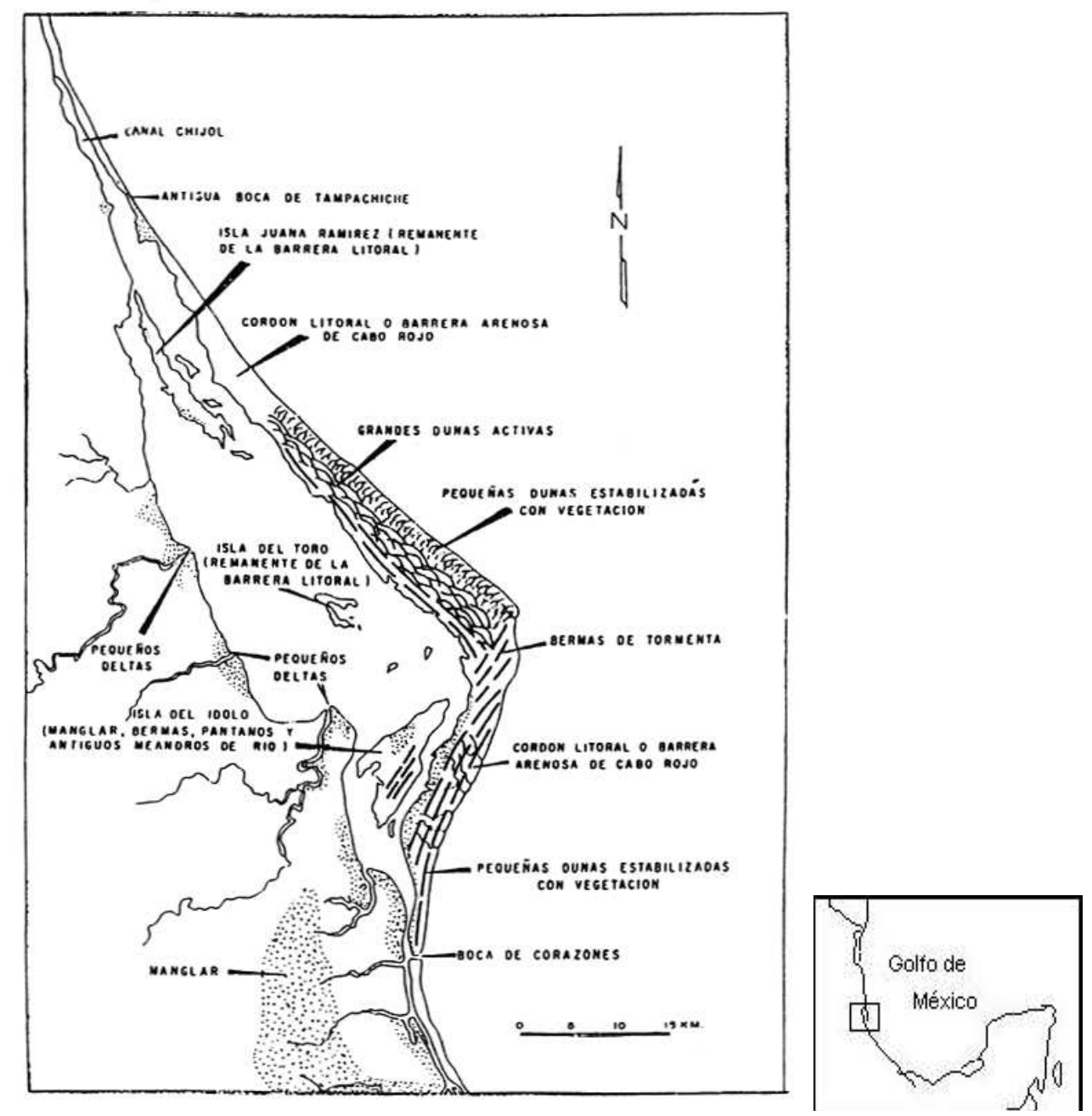

Figure 1. The Tamiahua wetlands localization

Source: Revista internacional de contaminación ambiental - Bioacumulación (2013).

The biodiversity of the place is rich, the area being inhabited by mollusk, crustacean, polychaeta, waterfowl, and a place for turtles laying eggs. Due to its ecology, botany, zoology, limnology, and hydrology richness, the Tamiahua was designated as a protected wetland included in the Ramsar Treaty of November 27th, 2005. The Ramsar Convention provides the framework for national action and international cooperation for the conservation and wise use of wetlands and their resources.

However, in the last ten years, a pollution problem has been affecting fishing activities in the lagoon. Industrial and residential pollutants are brought to the lagoon through 5 main rivers. The main types of pollutants are: hydrocarbon, agro-chemicals, fertilizers, metals and all sort of organic and solid waste (Albert, Bandala, Torres-Nacho, and Villanueva, 2006). 


\section{Socio-economic conditions}

Surrounding the Tamiahua Lagoon there are 5 municipalities with a total population of 205,000 inhabitants. The economically active population (EAP) amounts to 40 percent of total population (INEGI, 2005, 2010). The main economic activity in this region is concentrated in the primary sector, mainly agriculture, as 75 per cent of the EAP is located in this sector. Only 2.5 percent operate in the manufacturing sector, and the rest of the EAP work in the service sector (INEGI, 2005, 2010). The net rate of population growth in the region is estimated at 1.8 percent annually.

The fishing activity is carried out by approximately 4,000 people (Cooperativa Pesquera, Tamiahua, 2012). They are grouped in 340 business units known as fishing cooperatives, with an average size of 12 people. Out of 4,000 people, 60 percent, that is 2,400 , are proprietors of the business units, and the remaining 1,600 fishermen work as employees. It is estimated that the total fleet is composed of 680 fishing boats, which means an average of 2 boats per company.

According to recent data, annual fish catchment is about 12,750 tons. This amounts to an average catchment per boat of 18.75 tons per year, or 37.5 tons per company. The estimated price per ton in the intermediary market is US\$1,500.

The market price of a boat is US\$10,500, and it has a usable life of 20 years. The operating cost for each boat is estimated to run at US\$10,000 per year, including wages.

Cooperatives in Mexico, as the fishing ones in Tamiahua, normally receive financial support by the Federal Government. In particular, the Ministry for Agricultural and Fishing Resources decides on fishing permits and funding for cooperatives after an economic feasibility study.

\section{Model description}

The model TAMIAHUA1 consists of four main sectors and was built using Vensim PLE Version 5.8. The first two sectors are similar to the ones used on the Fishbanks model (Meadows, 2004), and include the fish population and the fleet size. The third sector includes population dynamics in the region, and the last sector considers the contamination level in the water of the wetlands.

Figure 2 shows the basic structure of fish population and fishing. The red parts in the model are those that are unique to the model presented in this study. The stock of diversity of the species was important to include, given the key role that this diversity plays on the cleaning function of wetlands and its impact on the growth of fish population. As shown in the figure, fishing practices in Tamiahua have been recognized to have an impact on the diversity 
of the species. Moreover, water contaminants and the diversity of the species have also had an impact on the population of fish in the lagoon.

Figures 3 and 4 represent the growth of the fishing fleet. Figure 3 includes the representation of the attractiveness of the fishing industry compared to other activities in the Tamiahua region. Profit is the difference between income and costs associated to fishing, and the profitability of other economic activities was estimated using the minimum wage in Mexico. As shown in Figure 4, the funding to increase fleet size does not come in this region from profits in the fishing industry, but from subsidies provided by the State government. As described by one of the experts involved in the modeling process, fishing cooperatives' need to increase the fleet or replace the existing boats exerts pressure on State government to provide more public funds to buy new boats.

Figure 5 shows the way in which the attractiveness of the fishing industry attracts Tamiahua region inhabitants to join (or leave) fishing cooperatives.

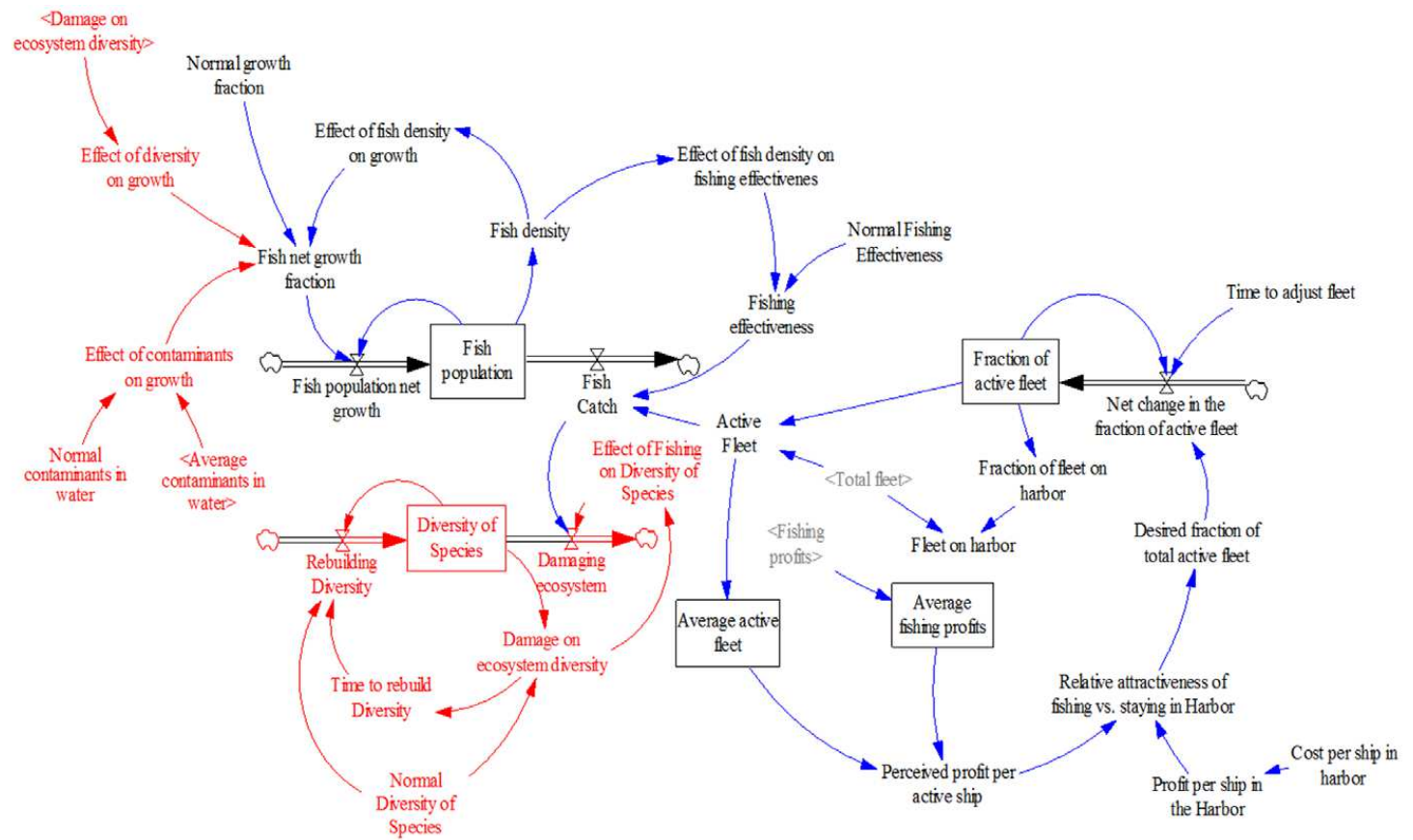

Figure 2. Fish population and fishing activities

Source: Authors' research on the basis of Meadows (2004). 


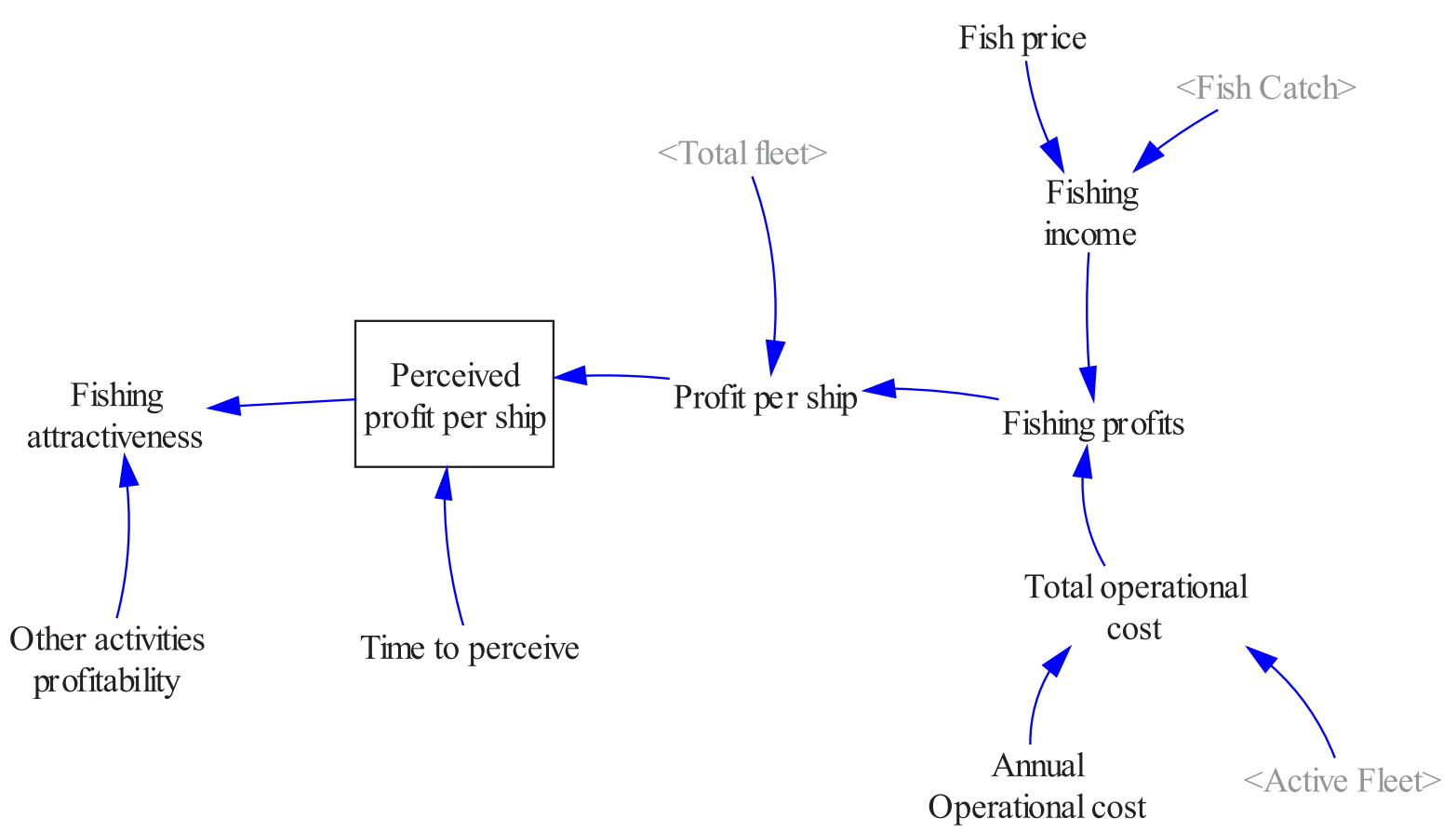

Figure 3. Fishing attractiveness

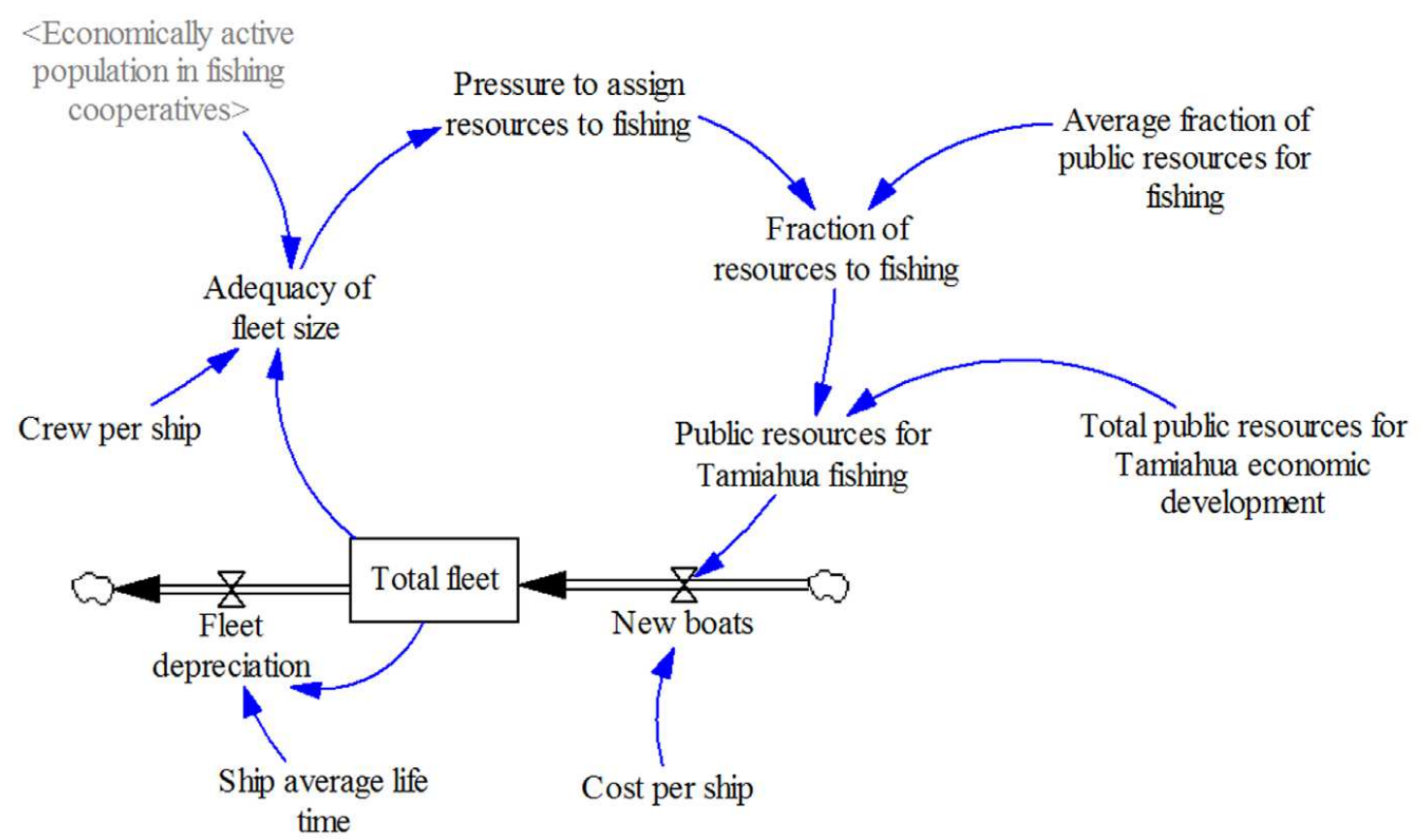

Figure 4. Fleet growth 


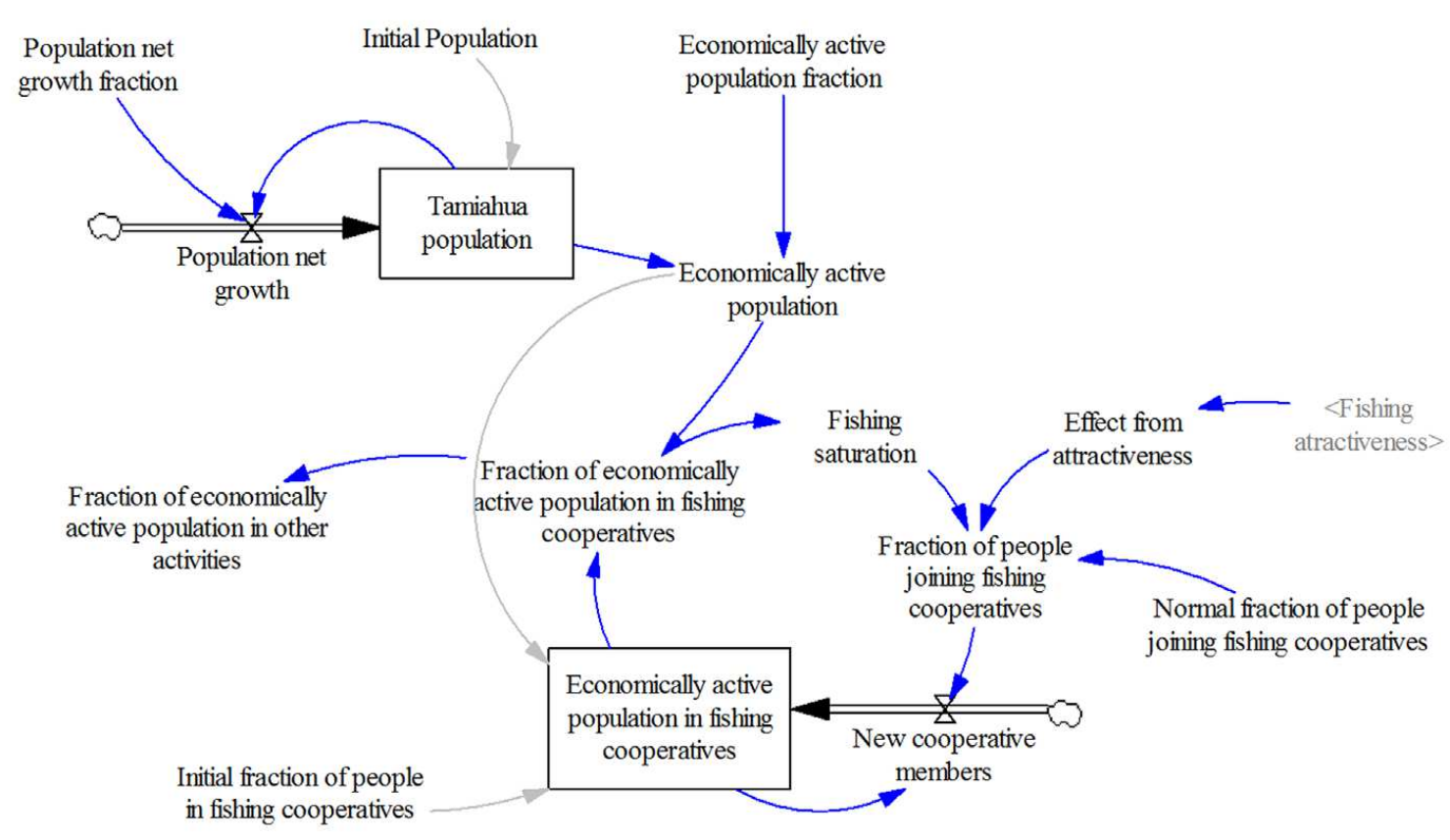

Figure 5. The Tamiahua population undertaking fishing activities

Finally, Figure 6 presents a theory of how contaminants come into the lagoon, and how the lagoon absorbs a fraction of these contaminants before the water reaches the sea. The Tamiahua lagoon has experienced a considerable increase on its pollution levels resulting from the release of chemicals produced in oil-related, industrial and agricultural activities in the zone. During the last fifty years, the system has received oil spills from crude exploitation facilities and oil pipelines. Besides, most of the municipalities settled in the surroundings of the lagoon lack sanitation systems producing domestic wastewater and leachates from solid waste sites are released without any treatment to the lagoon (Albert et al., 2006). As shown in figure 6 , contaminants coming from industrial effluents upstream in the rivers and from sewers and human activity may threaten the diversity of the species and have an impact on the absorption capacity of the Tamiahua Lagoon.

Appendix A shows the parameters values and equations that were used for the model. 


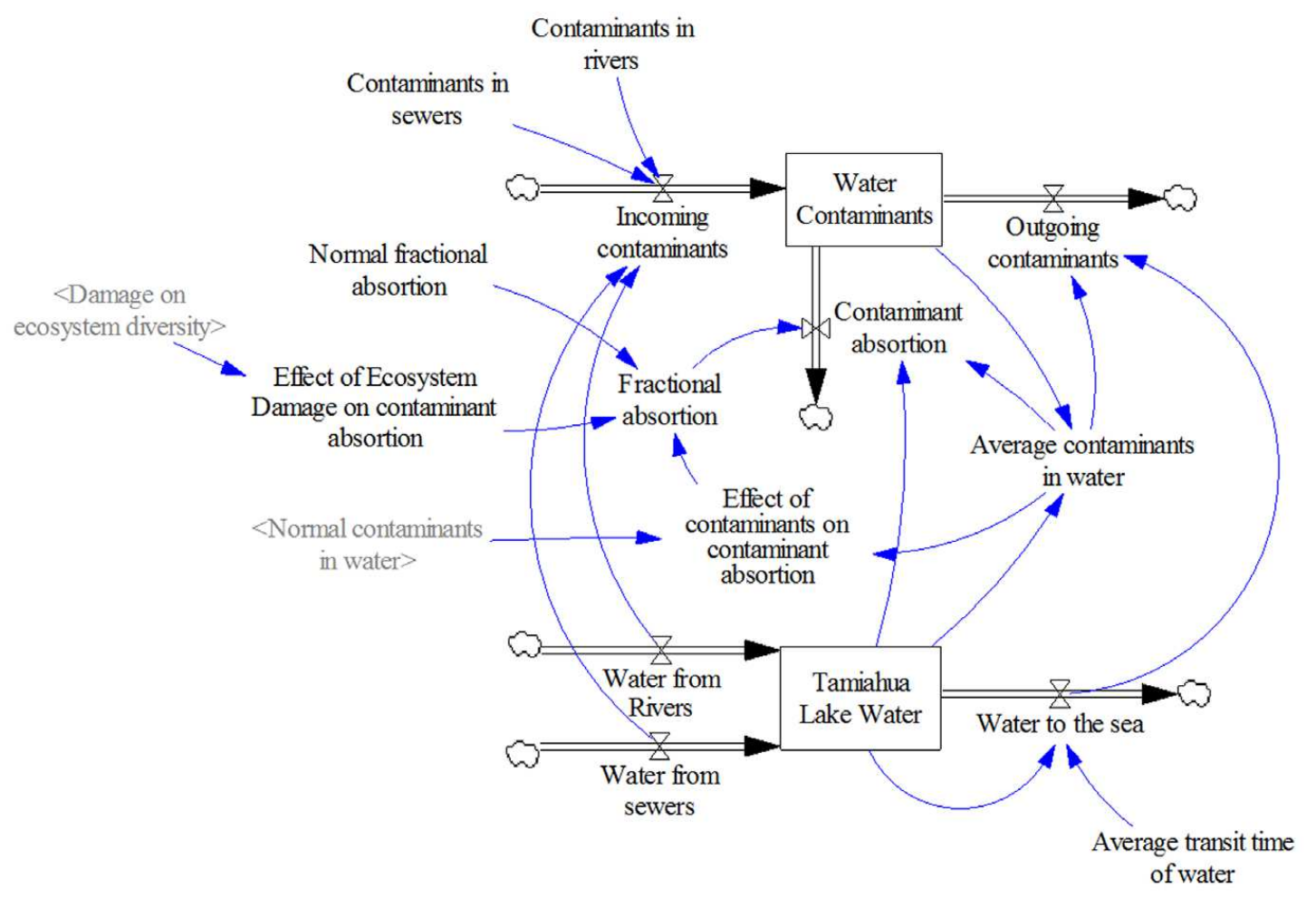

Figure 6. Contaminants in water

\section{Results and discussion}

Figures 7, 8 and 9 show some of the behaviors of the model in a base scenario. Figure 7 shows the way in which fishing activity slowly erodes the diversity of the species, eventually impairing the ability of the fish population to reproduce in a healthy way. Figure 8 shows the dynamic behavior of the fleet size, the active fleet and the fleet in harbor. As shown in the figure, the impact on the fish population promoted by contamination and the decrease on the diversity of the species is not yet enough in this model to have an impact on the fishing activities. Given that the actual fleet size is similar to the simulated fleet size, this base scenario suggests that the observed decrease on fishing activity in Tamiahua responds to the contamination of the wetlands or to the impact of the fishing techniques on the diversity of the species. 
$20 \mathrm{M}$ Fish Tons

$2 \mathrm{M}$ Fish Tons/year

400 Species $/ \mathrm{m} 3$

$13 \mathrm{M}$ Fish Tons

900,000 Fish Tons/year

200 Species $/ \mathrm{m} 3$

$6 \mathrm{M}$ Fish Tons

$-200,000$ Fish Tons/year

$0 \quad$ Species $/ \mathrm{m} 3$

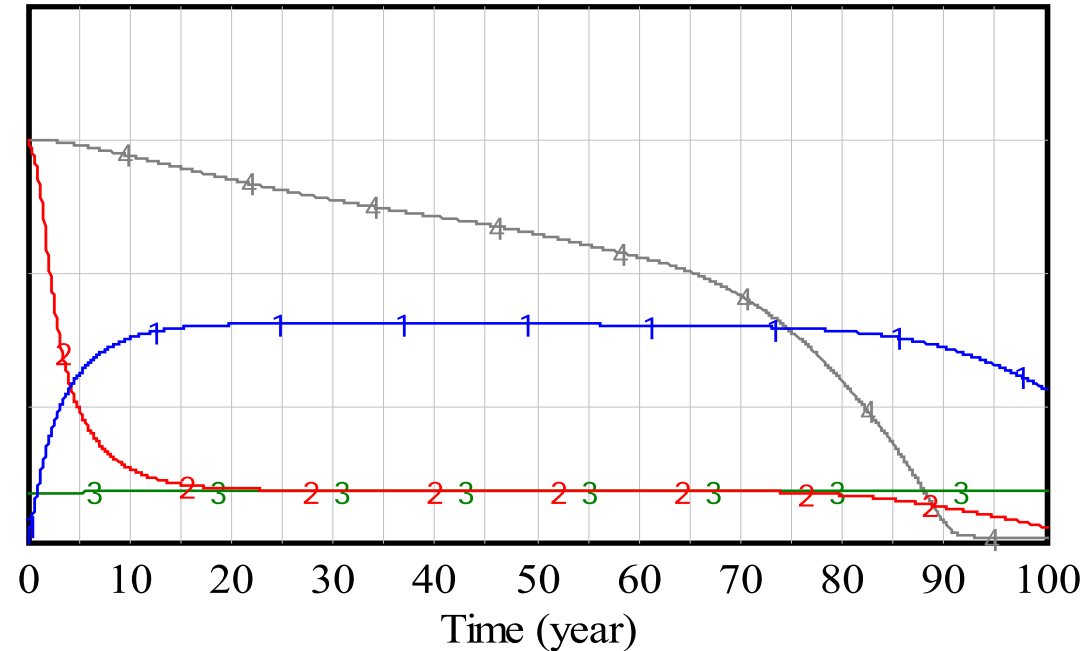

Fish popu lation : Base $\begin{array}{llllllll} & 1 & 1 & 1 & 1 & 1 & 1 & 1\end{array}$ Fish popu lation net growth : Base $\begin{array}{lllllll}2 & 2 & 2 & 2 & \text { Fish Tons/year }\end{array}$ Fish Catch: Base $\begin{array}{llllllll}3 & 3 & 3 & 3 & 3 & 3 & 3 & \text { Fish Tons/year }\end{array}$ $\begin{array}{lllllllll}\text { Diversity } \text { of Species : Base } & -4 & 4 & 4 & 4 & 4 & 4 & \text { Species } / \mathrm{m} 3\end{array}$

Figure 7. Fish population

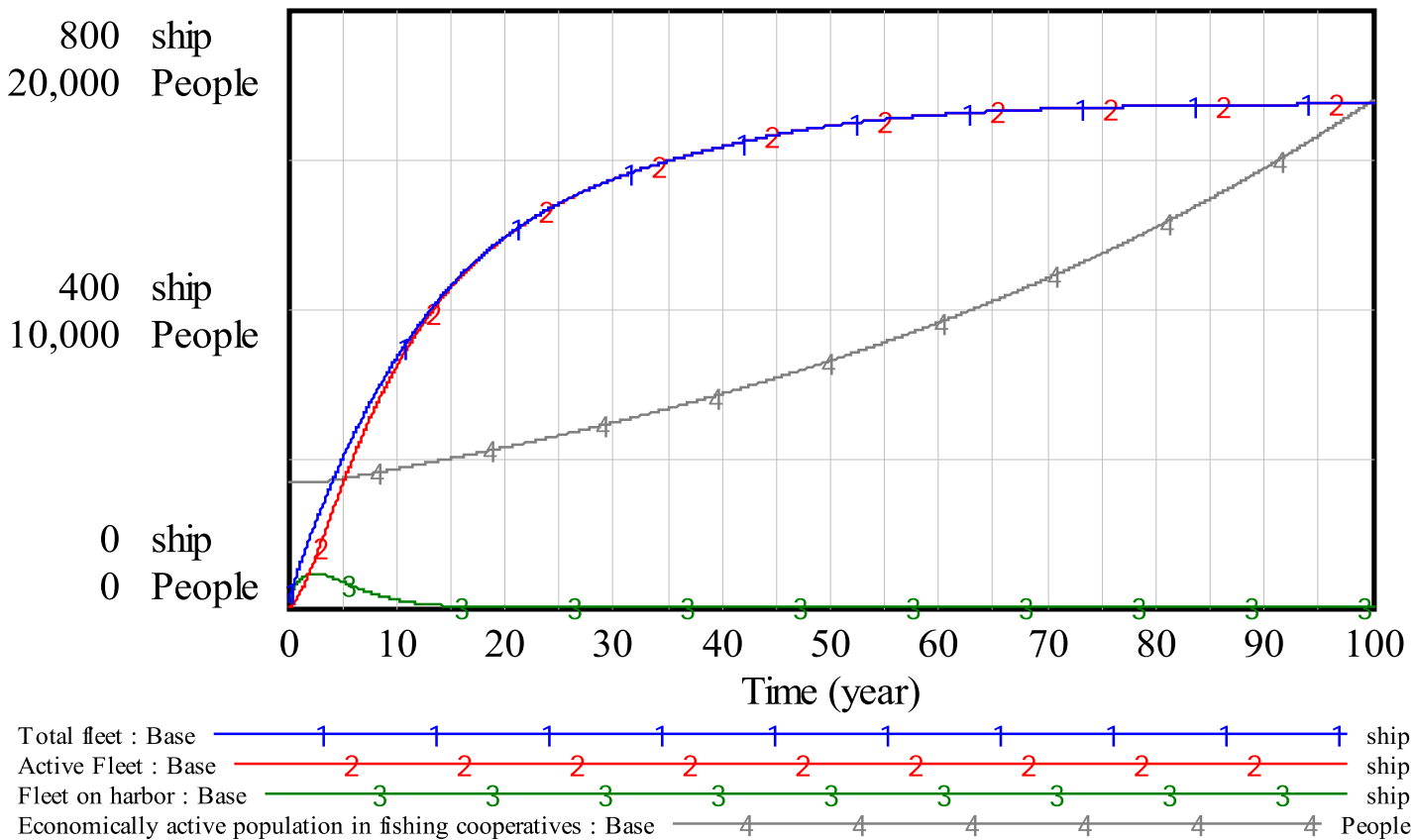

Figure 8. Fleet size and population 
Figure 9 shows some key behaviors of the ecosystem. During the last years of the simulation, it is possible to observe an important damage in the diversity of the species, which leads to an increase in contaminants in the lake, attributed mostly to the reduction in the capacity of the lagoon to absorb contaminants.

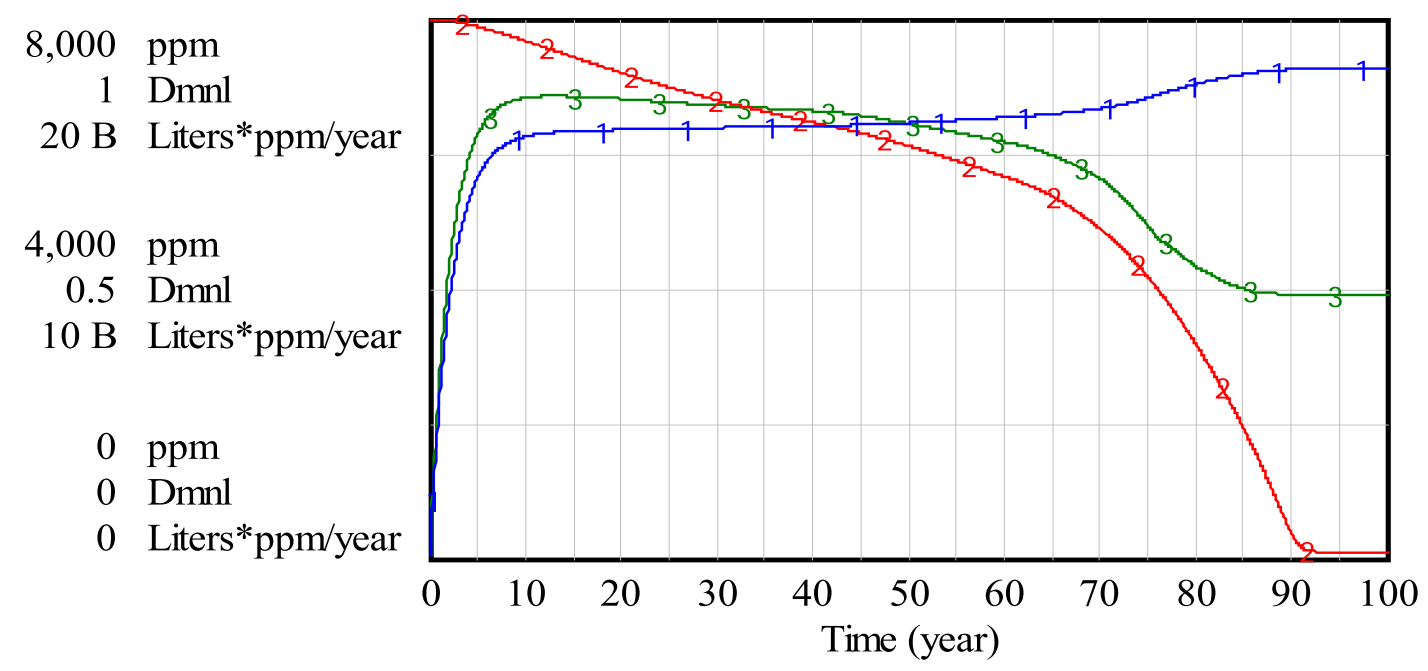

Average contaminants in water: Base $\begin{array}{llllllllllllll}1 & 1 & 1 & 1 & 1 & 1 & 1 & 1 & \text { ppm }\end{array}$ Damage on ecosystem diversity : Base $\begin{array}{lllllllllll}2 & 2 & 2 & 2 & 2 & 2 & 2 & 2 & 2 & 2\end{array}$

Contaminant absorption: Base $\begin{array}{llllllll}3 & 3 & 3 & 3 & 3 & 3 & 3 & \end{array}$ Notes:

Pppm: Parts per million.

Dmnl: Dimensionless, as it refers to Diversity of Species/Normal Diversity of Species.

Figure 9. Contaminants and ecosystem diversity

The initial explorations with the model involved 5 parameter changes producing also 5 basic scenarios. In the first scenario, we increased the damage on the ecosystem produced by the fishing activity. The second scenario consists of an increase in incoming contaminants to the lagoon. The third and fourth scenarios involve changes in the attractiveness of alternative economic activities, making fishing more or less attractive. The last scenario explores the impacts of increased resources from government to the fishing industry.

As shown in Figures 10 to 13, attractiveness of alternative economic activities have a very limited impact on model behavior. The main reason is that the main source of economic resources to increase the fleet size is government funds. An increase in government funds, on the other hand, does have an impact on the sustainability of the ecosystem because it allows for the fleet size growth, accelerating damage to the ecosystem, and collapse of the fishing industry. Increasing contaminants from rivers and changes in fishing practices for ones with higher environment impacts have an important impact on fish population. Increased contaminants have a more continuous impact, 
and increased impact from fishing practices contributes to a faster decline in fish population.

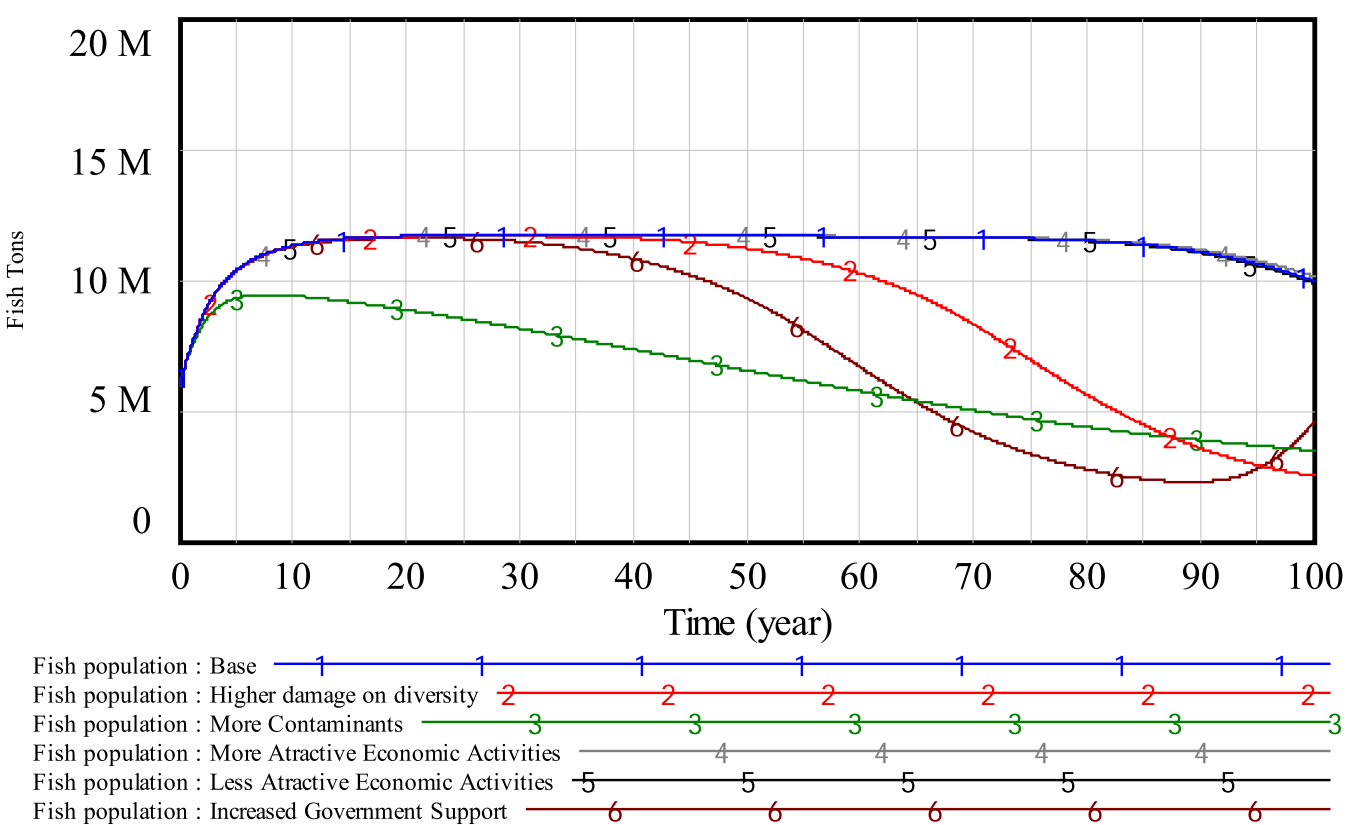

Figure 10. Comparative graph for fish population

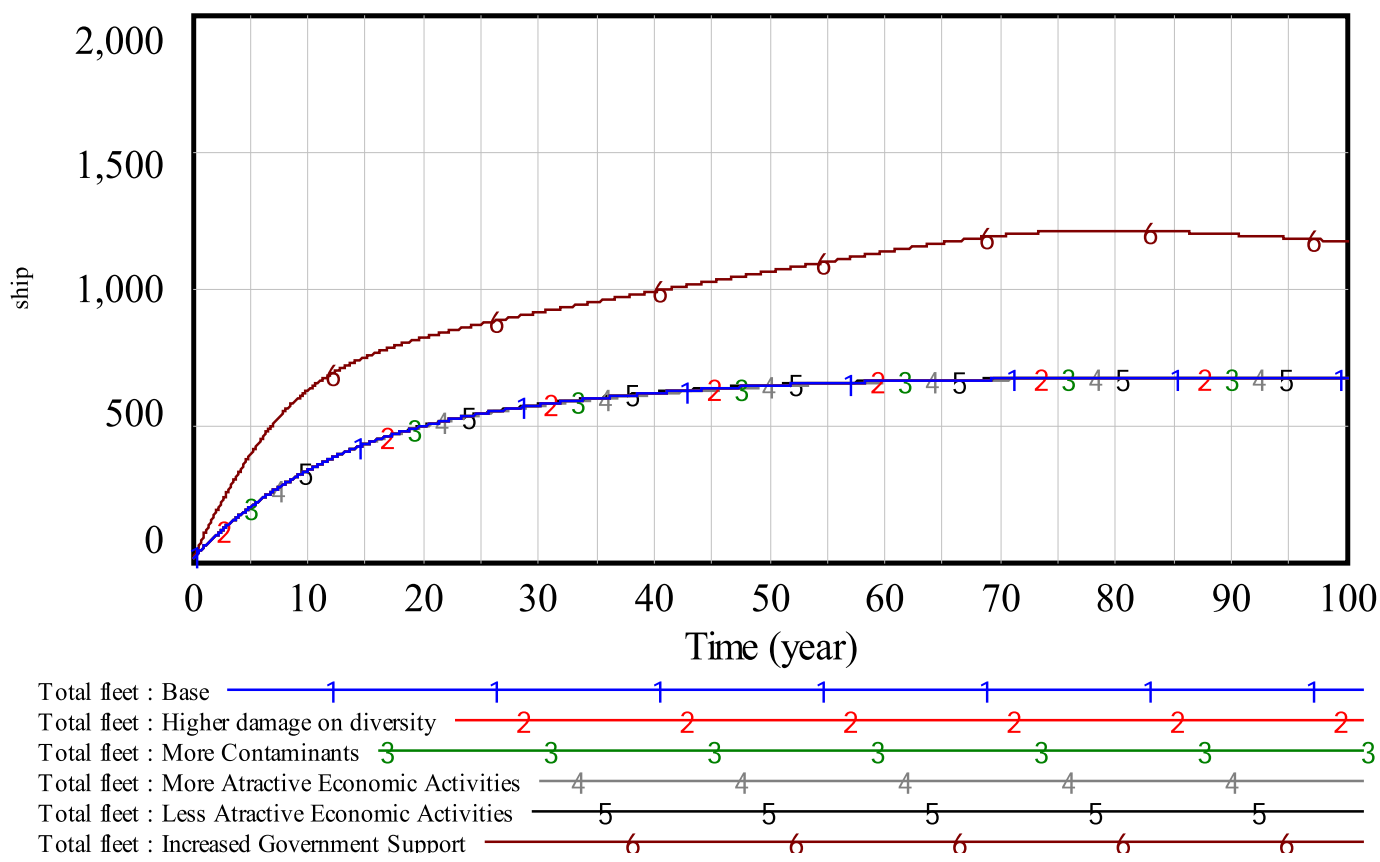

Figure 11. Comparative graph for total fleet 


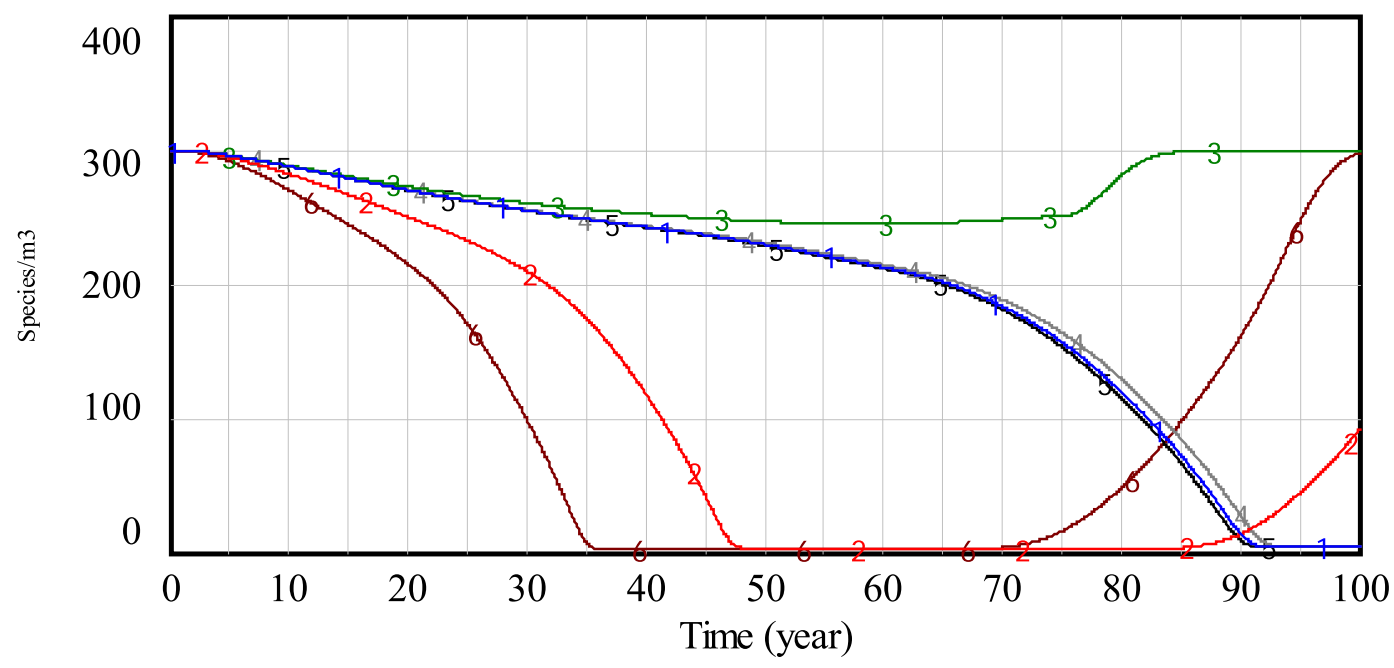

Diversity of Species : Base 1 1 112111

Diversity of Species : Higher damage on diversity $\begin{array}{lllll}2 & 2 & 2 & 2 \\ \text { Diversity of Species : More Contaminants } & 3 & 3 & 3 & 3\end{array}$ Diversity of Species : More Atractive Economic Activities

Diversity of Species : Less Atractive Economic Activities

Diversity of Species : Increased Government Support

\begin{tabular}{llllll}
\hline & 45 & 4 & 4 & & \\
6 & 5 & 5 & 5 & 5 & 5 \\
6 & & & 5 & & 6
\end{tabular}

Figure 12. Comparative graph for diversity of species

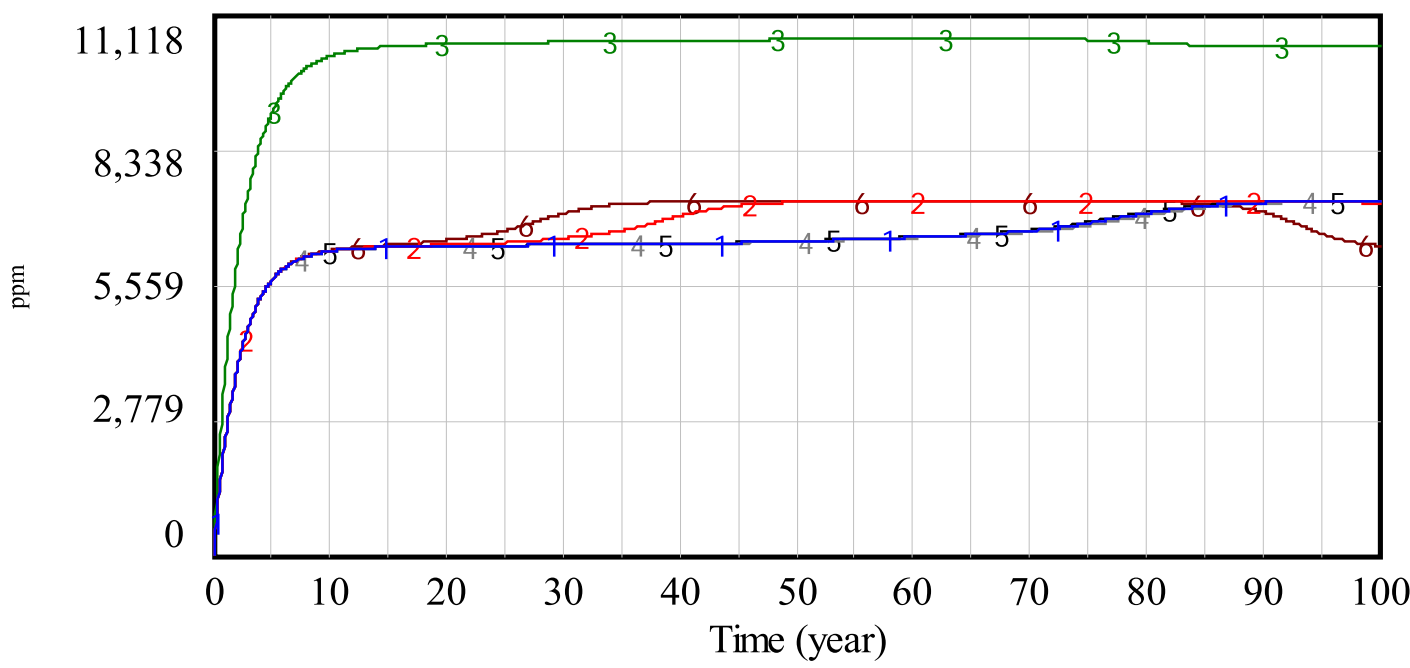

Average contaminants in water: Base 11011112

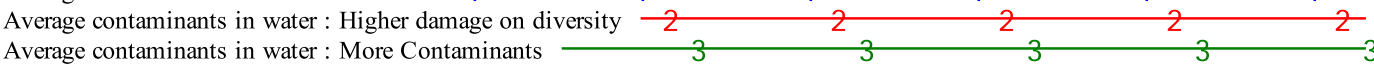

Average contaminants in water : More Contaminants
Average contaminants in water : More Atractive Economic Activities

Average contaminants in water: Less Atractive Economic Activities

Average contaminants in water : Increased Government Support

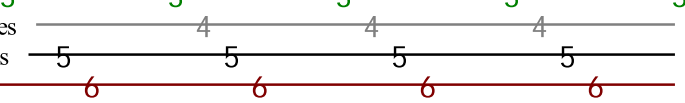

Figure 13. Comparative graph for contaminants in water 


\section{Conclusion}

In this short article, we presented a preliminary model to study the sustainability of the Tamiahua Lagoon considering the fishing activity and the impact this activity makes on the diversity of species in the lagoon. Additionally, the model includes the impact of contamination of the wetlands. Preliminary experiments suggest that fishing practices and contamination have the potential to create a significant imbalance in the system, apparently in a more important way that the actual fishing intensity.

Fishing activity is considerably limited by the availability of government funds. In this way, government decisions on funding the fishing activity affect the stability of the system.

Although the model presented in this study has a reasonable structure, it still needs to be refined in terms of parameter values, mostly those associated to the ecosystem. We will continue our experiments with the model to create a series of policy recommendations to the State Government of Veracruz in Mexico.

\section{References}

Albert, L., Bandala, E.R., Botello, A., Torres-Nachon, C., and Villanueva S. (2006). Toxic contaminants presence and its effects on health and environment at Tamiahua Lagoon, Veracruz. Consejo Estatal de Protección al Ambiente. Gobierno del Estado de Veracruz.

Cavana, R.Y. and Ford, A. (2004). Environmental and resource system Editors' introduction. System Dynamics Review, 20(2), 89-98.

Cooperativa Pesquera Tamiahua (2012). Datos anuales de Cooperativa Pesquera de Tamiahua. Registros anuales.

Forrester, J. (1961). Industrial Dynamics. Waltham, MIT, USA: Pegasus Communications.

Instituto Nacional de Estadística Geografía e Información (2005). Censos Económicos 2004, INEGI: México.

Instituto Nacional de Estadística Geografía e Información (2010). Censos Económicos 2009, INEGI: México.

Instituto Nacional de Estadística Geografía e Información (2006). Population and Housing Counting 2005, INEGI: México.

Instituto Nacional de Estadística Geografía e Información (2011). Population and Housing Counting 2010, INEGI: México.

Josephson, J. (1992). Status of wetlands. Environmental Science and Technology 26(3): 422.

Martínez Fernández, J. and Esteve Selma, M.A. (2004). The dynamics of water scarcity on irrigated landscapes: Mazarrón and Aguilas in south-eastern Spain. System Dynamics Review 20(2), 117-137. 
Meadows, D.L. (2004). FishBanks, Ltd. Durham, NH: Laboratory of Interactive Learning.

Morecroft, J. (2007). Fish and ships - fishery dynamics with bounded rationality. Paper presented at the 2007 International Conference of the System Dynamics Society, Boston, MA.

Otto, P. and Struben, J. (2004). Gloucester fishery: Insights from a group modeling intervention. System Dynamics Review, 20(4), 287-312.

Ruth, M. (1995). A system dynamics approach to modeling fisheries management issues: Implications for spatial dynamics and resolution. System Dynamics Review, 11(3), 233-243.

Stave, K.A. (2003). A systems dynamics model to facilitate public understanding of water management options in Las Vegas, Nevada. Journal of Environmental Management, 67, 303-313.

Richardson, G.P. and Pugh, A.L. (1989). Introduction to System Dynamics Modeling. Waltham MA: Pegasus Communications.

Sterman, J. (2000). Business Dynamics, Systems Thinking and Modeling for a Complex World. USA: Irwin McGraw-Hill.

Winz, I. and Brierley, G. (2007). The Use of System Dynamics Simulation in Integrated Water Resources Management. Paper presented at the Systems Dynamics Conference 2007, University of Auckland, New Zealand.

Wolstenholme, E.F. (1982). System Dynamics in Perspective. The Journal of the Operational Research Society, 33(6), 547-556.

Wolstenholme, E.F. (2003). Towards the definition and use of a core set of archetypal structures in system dynamics. System Dynamics Review, 19(1), 7-26.

\section{Electronic reference}

Revista internacional de contaminación ambiental - Bioacumulación (2013). Retrieved from:

https://www.google.com.mx/search?q=tamiahua+lagoon+mexico\&so urce $=\ln m s \& t b m=i s c h \& s a=X \& e i=P E J X U$ uqgD66FyQGRnoHADw\&ve $d=0 C A c Q$ AUoAQ\&biw $=1438 \& b i h=655 \& d p r=1 \# f a c r c=$ \&imgdii $=$ \&imgrc=Pq0Uon9RICfAeM\%3A\%3B_jd1Dj7iSR_9xM\%3Bhttp\%253 A\%252F\%252Fwww.scielo.org.mx\%252Fimg\%252Frevistas\%252F rica\%252Fv26n3\%252Fa3f1.jpg\%3Bhttp\%253A\%252F\%252Fwww. scielo.org.mx\%252Fscielo.php\%253Fpid\%253DS0188-499 $92010000300003 \% 2526$ script \%253Dsci_arttext\%3B462\%3 B598 


\section{Abstrakt (in Polish)}

Artykuł prezentuje wstępny symulacyjny model TAMIAHUA1, opracowany w celu dokonania analiz zwiqzanych z utrzymaniem naturalnego rezerwatu przyrody w Meksyku - mokradeł Tamiahua Wetlands. Mokradła sq często określane jako "nerki natury”, ponieważ stanowiq naturalny filtr oczyszczajacy zanieczyszczenia wodne. Pomimo ich znaczenia, sq one obszarami zagrożonymi. Punktem wyjścia do opracowania modelu przedstawionego w artykule był model przedstawiony przez Meadows (2004). Model ten rozbudowano między innymi o zmienne obrazujqce ekonomicznq aktywność ludności oraz wielkość zanieczyszczeń w wodzie. Badania na modelu sugeruja, że działalność połowowa na obszarach Tamiahua Wetlands wraz z rosnqcym poziomem zanieczyszczeń wynikajqcych z działalności człowieka mogq znaczq̨co wpłynqć na zmniejszenie różnorodności gatunków w ekosystemie Tamiahua, co może zagrozić jego zrównoważonemu rozwojowi. Dodatkowe badania według pięciu scenariuszy dostarczajq wniosków, które moga prowadzić do podjęcia takich decyzji, które mogłyby wpłynqć na zrównoważone zarzq̨dzanie rozwojem tamtejszego regionu.

Słowa kluczowe: zrównoważony rozwój, mokradła, Meksyk, Tamiahua.

\section{Appendix A. Parameters and model equations}

(001) $\quad$ Active Fleet $=$ Total fleet $*$ Fraction of active fleet

Units: ship

Number of ships fishing in the Wetlands

(002) Adequacy of fleet size $=$ (Economically active population in fishing cooperatives $/$ Crew per ship) / Total fleet

Units: Dmnl

A ratio describing how well the current fleet employ people in Tamiahua. A ratio greater than reveals unemployed people

(003) Annual Operational cost $=245000$

Units: pesos/(year*ship)

Cost of operating an active ship per year

(004) Average active fleet $=$ SMOOTH ( Active Fleet, Time to register average) Units: ship

Average number of ships fishing in Tamiahua

(005) Average contaminants in water = Water Contaminants / Tamiahua Lake Water Units: ppm

Water contaminants measured in parts per million

(006) Average fishing profits $=$ SMOOTH ( Fishing profits, Time to register average) Units: pesos/year

Average profits from fishing per year

(007) Average fraction of public resources for fishing $=0.1$

Units: Dmnl

The average represents the importance to subsidize fishing by local government.

(008) Average transit time of water $=3$

Units: year

This is the time that takes for water coming from rivers to reach the sea in its transit through the Wetlands

(009) Contaminant absorption = Average contaminants in water * Tamiahua Lake Water * Fractional absorption

Units: Liters*ppm/year 
This rate represents the cleaning process that happens in the Wetlands

(010) Contaminants in rivers $=5000$

Units: ppm

These are contaminants coming from rivers, regularly they are fertilizers that accumulate in the river because of agricultural activities

(011) Contaminants in sewers $=12000$

Units: ppm

These are contaminants coming from sewers, regularly these contaminants are city residuals that accumulate in the river because of urban activities, both residential and industrial

(012) Cost per ship $=250000$

Units: pesos/ship

The cost of a ship in pesos

(013) Cost per ship in harbor $=50$

Units: pesos/(year*ship)

The cost of having a ship in harbor per year

(014) Crew per ship $=6$

Units: People/ship

The number of people needed to man a ship

(015) Damage constant $=0.0015$

Units: Species/(Fish Tons*m3) [0,1,0.001]

A constant representing the damage on the diversity in species because of fishing.

The diversity is important for the cleaning process that happens in the Wetlands

(016) Damage on ecosystem diversity = Diversity of Species / Normal Diversity of Species

Units: Dmnl

This is the current status of the Wetlands relative to the normal count of species.

(017) Damaging ecosystem $=$ Fish Catch * Effect of Fishing on Diversity of Species

Units: Species/(year*m3)

This outflow represents erosion in the ecosystem as a result of fishing practices

(018) Desired fraction of total active fleet = DFTFC $\mathrm{f}$ ( "Relative attractiveness of fishing vs. staying in Harbor")

Units: Dmnl

This fraction determines the number of ships fishing as a result of the profitability of fishing

(019) DFTFC $f([(-2,0)-(2,1)],(-2,1),(-1.6,0.98),(-1.2,0.9),(-0.8,0.8),(-0.4,0.66),(0,0.5),(0.4,0.34)$, $(0.8,0.2),(1.2,0.1),(1.6,0.02),(2,0))$

Units: Dmnl

This is the function of the fraction of ships fishing. The more profitable the fishing is, the more ships do it.

(020) Diversity of Species = INTEG( Rebuilding Diversity - Damaging ecosystem, Normal

Diversity of Species )

Units: Species/m3

A level representing current bio-diversity in Tamiahua wetlands.

(021) $\quad \operatorname{ECCAf}([(0,0.5)-(2,1.5)],(0,1.2),(0.2,1.19737),(0.4,1.18421),(0.6,1.15789),(0.8,1.09649)$, $(1,1),(1.2,0.864035),(1.4,0.710526),(1.6,0.600877),(1.8,0.530702),(2,0.5))$

Units: Dmnl

This function describes the ability of the Wetlands to clean themselves under different concentrations of contaminants.

(022) ECFNG $\mathrm{f}([(0,-1)-(2,1)],(0,1),(0.2,0.903509),(0.4,0.719298),(0.6,0.5),(0.8,0.27193)$,

$(1,0),(1.2,-0.192982),(1.4,-0.307018),(1.6,-0.385965),(1.8,-0.45614),(2,-0.5))$

Units: Dmnl

This function describes the impacts of water contamination on the ability of the fish population to reproduce

(023) Economically active population = Economically active population fraction* Tamiahua population

Units: People 
(024)

People in working age available to work outside home

Economically active population fraction $=0.3$

Units: Dmnl

Fraction of people in working age available to work outside home

(025) Economically active population in fishing cooperatives = INTEG( New cooperative members, Initial fraction of people in fishing cooperatives * Economically active population)

Units: People

People working in coop fisheries

(026) EDCFG $f([(0,-4)-(2,2)],(0,0.8),(0.2,1.07895),(0.4,1.26316),(0.6,1.21053),(0.8,0.921053)$,

$(1,0.394737),(1.19878,-0.0526316),(1.38226,-0.473684),(1.57187,-1.02632)$,

$(1.78593,-1.5),(2,-2.13158))$

Units: Dmnl

This function represents the ability of the fish population to reproduce, given a certain

fish density

(027) EDG $f([(0,-1)-(1,1)],(0,-0.5),(0.1,-0.464912),(0.2,-0.403509),(0.3,-0.289474)$,

$(0.4,-0.149123),(0.5,0),(0.6,0.22807),(0.7,0.491228),(0.8,0.754386),(0.9,0.903509),(1,1))$

Units: Dmnl

This function describes the impacts of bio-diversity on the ability of the fish population to reproduce

(028) $\quad \operatorname{EEDCA} f([(0,0)-(1,1)],(0,0.5),(0.1,0.504386),(0.2,0.508772),(0.3,0.530702)$, $(0.4,0.570175),(0.5,0.635965),(0.6,0.763158),(0.7,0.855263),(0.8,0.938596),(0.9,0.973684)$, $(1,1))$

Units: Dmnl

This function describes the impacts of bio-diversity on the ability of the Wetlands to clean themselves

(029) $\quad \operatorname{EFA~} \mathrm{f}([(0,-1)-(2,1.2)],(0,-0.5),(0.2,-0.150877),(0.4,0.157895),(0.6,0.466667),(0.8,0.727193)$, $(1,1),(1.2,1.13246),(1.4,1.1807),(1.6,1.1807),(1.8,1.1807),(2,1.2))$

Units: Dmnl

This function describes the impacts of fishing attractiveness on the number of people that wants to work on this industry

(030) $\quad \operatorname{EFDS} f([(0,0)-(1,1.2)],(0,0),(0.025,0.6),(0.05,0.8),(0.075,0.95),(0.1,0.99),(0.2,1),(0.3,1)$, $(0.4,1),(0.5,1),(0.6,1),(0.7,1),(0.8,1),(0.9,1),(1,1))$

Units: Dmnl

This function describes the effect of fishing practices on bio-diversity

(031) Effect from attractiveness = EFA $f$ ( Fishing attractiveness )

Units: Dmnl

The fishing attractiveness function

(032) Effect of contaminants on contaminant absorption = ECCA f ( Average contaminants in water / Normal contaminants in water )

Units: Dmnl

The effect of contaminants on contaminant absorption

(033) Effect of contaminants on growth = ECFNG $\mathrm{f}$ ( Average contaminants in water / Normal contaminants in water )

Units: Dmnl

The impact of contamination on the fish population ability to regenerate

(034) Effect of diversity on growth = EDG $f$ ( Damage on ecosystem diversity)

Units: Dmnl

The effect of bio-diversity on the fish population ability to reproduce

(035) Effect of Ecosystem Damage on contaminant absorption = EEDCA $f($ Damage on ecosystem diversity)

Units: Dmnl

The impact of bio-diversity on the ability of the Wetlands of cleaning themselves

(036) Effect of fish density on fishing effectiveness = SEDC $f$ ( Fish density)

Units: Dmnl 
The impact of fish density on fishing

(037) Effect of fish density on growth = EDCFG $\mathrm{f}$ ( Fish density )

Units: Dmnl

The impact of fish density on fish population net growth

(038) Effect of Fishing on Diversity of Species = Damage constant * EFDS $f($ Damage on ecosystem diversity )

Units: Species/(Fish Tons*m3)

The impact of fishing on the wetlands bio-diversity

(039) FINAL TIME $=100$

Units: year

The final time for the simulation.

(040) Fish Catch $=$ Active Fleet $*$ Fishing effectiveness

Units: Fish Tons/year

This rate describes the yearly catch

(041) Fish density = Fish population / Tamiahua lake carrying capacity

Units: Dmnl

A ratio describing how much fish are in the Wetlands compared to the total capacity

(042) Fish net growth fraction = Effect of fish density on growth * Effect of contaminants on growth* Effect of diversity on growth * Normal growth fraction

Units: 1 /year

This is the yearly growth fraction considering all factors that have an impact on it

(043) Fish population = INTEG ( Fish population net growth - Fish Catch, 6e+006)

Units: Fish Tons

Fish population in the Tamiahua wetlands

(044) Fish population net growth $=$ Fish population * Fish net growth fraction

Units: Fish Tons/year

The Fish population net growth rate

(045) $\quad$ Fish price $=15000$

Units: pesos/Fish Tons

Price per fish ton

(046) Fishing attractiveness $=$ Perceived profit per ship / Other activities profitability

Units: Dmnl

A ratio comparing fishing profitability to the profitability of other economic activities

(047) Fishing effectiveness $=$ Normal Fishing Effectiveness * Effect of fish density on fishing effectiveness

Units: Fish Tons/(year*ship)

The effectiveness of every ship in catching fish, as a function of fish density

(048) Fishing income $=$ Fish Catch * Fish price

Units: pesos/year

Total income from fishing

(049) Fishing profits = Fishing income - Total operational cost

Units: pesos/year

Net profit from fishing

(050) Fishing saturation $=\mathrm{FS} f($ Fraction of economically active population in fishing cooperatives)

Units: Dmnl

The current limits of job supply in the fishing industry

(051) Fleet depreciation $=$ Total fleet $/$ Ship average life time

Units: ship/year

Fleet depreciates linearly on a given average life time

(052) Fleet on harbor $=$ Total fleet $*$ Fraction of fleet on harbor

Units: ship

Number of ships that are left on the harbor instead of going fishing

(053) Fraction of active fleet $=$ INTEG ( Net change in the fraction of active fleet, 0.05)

Units: Dmnl 
The fraction of ships that are actually fishing

(054) Fraction of economically active population in fishing cooperatives = Economically active population in fishing cooperatives / Economically active population

Units: Dmnl

The fraction of people working in fishing cooperatives

(055) Fraction of economically active population in other activities $=1$ - Fraction of economically active population in fishing cooperatives

Units: Dmnl

The fraction of people working in other industries different from fishing

(056) Fraction of fleet on harbor $=1$ - Fraction of active fleet

Units: Dmnl

This is the fraction of the fleet that cooperatives decide to keep on the harbor

Fraction of people joining fishing cooperatives $=$ Effect from attractiveness * Fishing

saturation * Normal fraction of people joining fishing cooperatives

Units: $1 /$ year

The fraction of people joining the fishing industry because of the attractiveness of the industry, as well as the demand for crew members

(058) Fraction of resources to fishing = Average fraction of public resources for fishing * Pressure to assign resources to fishing

Units: Dmnl

The actual amount of public money to invest in fishing cooperatives

(059) Fractional absorption = Effect of contaminants on contaminant absorption * Effect of

Ecosystem Damage on contaminant absorption * Normal fractional absorption

Units: $1 /$ year

The fraction of contaminants that the Wetlands can manage per year

(060) FS f $([(0,0)-(1,1.3)],(0,1.2),(0.1,1.2),(0.2,1.2),(0.3,1.19167),(0.4,1.15746),(0.5,1.11184)$,

$(0.6,1.04912),(0.7,0.992105),(0.8,0.87807),(0.9,0.615789),(1,0))$

Units: Dmnl

The function of job supply saturation in the fishing industry

(061) Incoming contaminants = Contaminants in rivers * Water from Rivers + Contaminants in sewers * Water from sewers

Units: Liters*ppm/year

Total contaminants incoming into the Wetlands

(062) Initial fraction of people in fishing cooperatives $=0.07$

Units: Dmnl

Model assumption about the initial value of the fraction of people working in the fishing industry

(063) Initial Population $=200000$

Units: People

Model assumption about initial values of the population in the region

(064) INITIAL TIME $=0$

Units: year

The initial time for the simulation.

(065) Net change in the fraction of active fleet $=($ Desired fraction of total active fleet - Fraction of active fleet ) / Time to adjust fleet

Units: $1 /$ year

The rate adjusting the fraction of fleet fishing per year

(066) New boats $=$ Public resources for the Tamiahua fishing / Cost per ship

Units: ship/year

Ship construction rate, assuming that all ship construction is subsidized by government

(067) New cooperative members = Fraction of people joining fishing cooperatives *

Economically active population in fishing cooperatives

Units: People/year

The rate of new workers joining the fishing industry 
(068) Normal contaminants in water $=10000$

Units: ppm

Reference value for contaminants in the Wetlands

(069) Normal Diversity of Species $=300$

Units: Species/m3

Reference value for diversity in the Wetlands

(070) Normal Fishing Effectiveness $=20$

Units: Fish Tons/(year*ship)

Average fishing capacity per boat

(071) Normal fraction of people joining fishing cooperatives $=0.01$

Units: 1/year

Average growth of workforce in the fishing industry

(072) Normal fractional absorption $=0.1$

Units: 1/year

Average absorption of contaminants

(073) Normal growth fraction $=0.2$

Units: 1/year

Average fertility of the fish population per year

(074) Other activities profitability $=20000$

Units: pesos/(year*ship)

Average profit in other industries competing with the fishing industry

(075) Outgoing contaminants = Water to the sea * Average contaminants in water

Units: Liters*ppm/year

Contaminants that leave the Wetlands into the sea

(076) PARF $f([(0,0)-(2,2)],(0,0),(0.2,0.105263),(0.4,0.298246),(0.6,0.517544),(0.8,0.77193)$,

$(1,1),(1.2,1.2193),(1.4,1.37719),(1.6,1.4386),(1.8,1.45614),(2,1.5))$

Units: Dmnl

The function describing the effect of the adequacy of the fleet size into the pressure to build more ships by government

(077) Perceived profit per active ship = Average fishing profits / Average active fleet

Units: pesos/(year*ship)

The perception of profit of ships fishing that will have an impact on the fraction of active

boats

(078) Perceived profit per ship = SMOOTH ( Profit per ship, Time to perceive)

Units: pesos/(year*ship)

Perception of ship profitability. Which will have an impact on working in the fishing industry

(079) Population net growth = Population net growth fraction * Tamiahua population

Units: People/year

Net rate of population growth

(080) Population net growth fraction $=0.015$

Units: 1/year

Average population growth

(081) Pressure to assign resources to fishing = PARF $f$ ( Adequacy of fleet size)

Units: Dmnl

A function of the adequacy of job supply in the fishing industry

(082) Profit per ship = Fishing profits $/$ Total fleet

Units: pesos/(year*ship)

(083) Profit per ship in the Harbor $=0$ - Cost per ship in harbor

Units: pesos/(year*ship)

A reference value to decide on sending ships to fish

(084) Public resources for Tamiahua fishing = Fraction of resources to fishing * Total public

resources for Tamiahua economic development

Units: pesos/year

Amount of public money used to increase the fleet 
(085) Rebuilding Diversity $=$ ( Normal Diversity of Species - Diversity of Species) $/$ Time to rebuild Diversity

Units: Species/(year*m3)

Regeneration of the Wetlands ecosystem

(086) "Relative attractiveness of fishing vs. staying in Harbor" = Perceived profit per active ship / Profit per ship in the Harbor

Units: Dmnl

A ration comparing active boats profit to costs of staying idle

(087) SAVEPER = TIME STEP

Units: year

The frequency with which output is stored.

(088) SEDC $f([(0,0)-(2,1.5)],(0,0),(0.149847,0.447368),(0.388379,0.754386),(0.599388,0.912281)$, $(0.798165,0.960526),(1,1),(1.19878,1.03947),(1.41896,1.08553),(1.59633,1.16447),(1.8,1.2)$, $(2,1.2))$

Units: Dmnl

The relationship between fish density and ship effectiveness

(089) Ship average life time $=15$

Units: year

Working life of a boat

(090) Tamiahua lake carrying capacity $=1 \mathrm{e}+007$

Units: Fish Tons

Estimated max fish population

(091) Tamiahua Lake Water = INTEG (Water from Rivers + Water from sewers - Water to

the sea, 2.4e+007)

Units: Liters

Total water in the wetlands

(092) Tamiahua population = INTEG( Population net growth, Initial Population)

Units: People

Total population

(093) TIME STEP $=0.0625$

Units: year

The time step for the simulation.

(094) Time to adjust fleet $=3$

Units: year

Average time to make changes on the fraction of active fleet

(095) Time to perceive $=2$

Units: year

Average time to perceive fishing industry profitability

(096) Time to rebuild Diversity = WITH LOOKUP( Damage on ecosystem diversity, $([(0,0)-(1,50)]$, $(0,50),(0.1,34.6491),(0.2,25.4386),(0.3,18.6404),(0.4,14.693),(0.5,10.7456),(0.6,7.45614)$,

$(0.7,4.82456),(0.8,3.28947),(0.9,2.19298),(1,1)))$

Units: year

A function describing the effect of ecosystem damage on the ability of the wetlands

to regenerate

(097) Time to register average $=1$

Units: year

Average reporting time in the fishing industry

(098) Total fleet = INTEG ( New boats - Fleet depreciation, 10)

Units: ship

(099) Total operational cost $=$ Annual Operational cost * Active Fleet

Units: pesos/year

Total cost of active fleet

(100) Total public resources for Tamiahua economic development $=7.5 \mathrm{e}+007$

Units: pesos/year 
Public resources available

(101) Water Contaminants = INTEG (Incoming contaminants - Contaminant absorption -

Outgoing contaminants, 1e+009)

Units: Liters*ppm

Total contaminants on the wetlands

(102) Water from Rivers $=4 \mathrm{e}+006$

Units: Liters/year

Water incoming from rivers

(103) Water from sewers $=4 \mathrm{e}+006$

Units: Liters/year

Water incoming from sewers

(104) Water to the sea = Tamiahua Lake Water / Average transit time of water

Units: Liters/year

Water flowing to the sea 